\title{
Nocardia coeliaca, Nocardia autotrophica, and the Nocardin Strain
}

\author{
RUTH E. GORDON, DOROTHY A. BARNETT, JOANNE E. HANDERHAN, \\ and C. HOR-NAY PANG \\ Institute of Microbiology, Rutgers University, The State University of New Jersey, New Brunswick, \\ New Jersey 08903
}

\begin{abstract}
Gray and Thornton's strain (ATCC 17041) of Mycobacterium coeliacum, here designated as the type strain of this species (which was later transferred to the genus Nocardia as Nocardia coeliaca), is a strain of $M$. rhodochrous (tentative generic assignment). The strain producing the antibiotic nocardin and similar strains, however, have been mistakenly labeled $N$. coeliaca. This report presents some of the characteristics of 27 of these mislabeled strains and demonstrates their close relationship to the type strain of $N$. autotrophica (Takamiya and Tubaki) Hirsch. The nocardin-producing strain and others like it are, therefore, assigned to $N$. autotrophica.
\end{abstract}

In 1928 Gray and Thornton (8) described an isolate from soil and named it Mycobacterium coeliacum. Later Jensen $(11,12)$ studied Gray and Thornton's strain, supplemented its description, and proposed that it typify subgenus B of the genus Mycobacterium.

In the 1930's, C. B. van Niel (personal communication) obtained Gray and Thornton's strain of $M$. coeliacum from Jensen and later deposited it in the American Type Culture Collection (ATCC strain 17041). Recently, after examining this strain Jensen (personal communication) confirmed the authenticity of the strain and its history.

When Waksman and Henrici (19) transferred $M$. coeliacum to the genus Nocardia, their description of the species was taken from the reports of Gray and Thornton (8) and Jensen (11). Because of its history, its general agreement with Gray and Thornton's original description of $M$. coeliacum, and Jensen's acceptance of it as Gray and Thornton's strain, we designate ATCC strain 17041 as the type strain of $N$. coeliaca.

In 1947 Emmart (5) described nocardin, an antibiotic produced by an air-borne contaminant of a broth culture of $M$. tuberculosis. In Emmart's report, her nocardin-producing strain was described as exhibiting an abundance of aerial hyphae on most media and was named Nocardia coeliaca (Gray and Thornton) nov. comb. (sic). Emmart's strain and others like it are maintained as $N$. coeliaca in various collections including the National Collection of Industrial Bacteria (NCIB strains 8939 and
9574), the American Type Culture Collection (ATCC strain 13181), and the U.S. Department of Agriculture (NRRL strains B-1365 and B-1807).

We have compared Gray and Thornton's strain (obtained from two sources) with Emmart's nocardin strain and similar ones in our collection. Although chronic "lumpers," we concluded that these strains belong to different species of different genera. Jensen also examined a nocardin strain (NCIB 8939) and concurred with our conclusion (personal communication).

Among the named strains of Nocardia species in our collection, only one, a strain of $N$. autotrophica (Takamiya and Tubaki [18]) Hirsch (9), has the same pattern of characteristics as the nocardin-producing strain.

\section{MATERIALS AND METHODS}

Organisms. Gray and Thornton's (8) strain of Mycobacterium coeliacum was obtained from the ATCC (strain 17041) and from V. B. D. Skerman, University of Queensland (strain 132). The other strains described are listed in Table 1 or by Gordon (6) and Gordon and Horan (7).

Acid fastness. The cultures were grown for 5 days at $28 \mathrm{C}$ on glycerol agar that consisted of: peptone, $5 \mathrm{~g}$; beef extract, $3 \mathrm{~g}$; agar, $15 \mathrm{~g}$; glycerol, $70 \mathrm{ml}$; soil extract, $150 \mathrm{ml}$; tap water, $850 \mathrm{ml}$; adjusted to $\mathrm{pH}$ 7.0. The soil extract was prepared by sifting air-dried garden soil through a coarse sieve and autoclaving 400 $\mathrm{g}$ with $960 \mathrm{ml}$ of tap water at $121 \mathrm{C}$ for $1 \mathrm{~h}$. After the mixture was cool and settled, the supernatant was carefully decanted, filtered through paper, autoclaved 
in 200-ml quantities, and stored at room temperature until cleared by sedimentation.

Smears of the cultures were air dried and immersed in carbol fuchsin (saturated ethanol solution of basic fuchsin, $10 \mathrm{ml} ; 5 \%$ aqueous solution of phenol, 90 $\mathrm{ml}$ ). The fuchsin was heated and boiled for $5 \mathrm{~min}$. The slides were washed in water, dipped once in acid alcohol (concentrated $\mathrm{HCl}, 3 \mathrm{ml} ; 95 \%$ ethanol, $97 \mathrm{ml}$ ), quickly washed again in water, and counterstained with methylene blue (saturated solution of methylene blue in $95 \%$ ethanol, $30 \mathrm{ml} ; 0.01 \%$ aqueous solution of $\mathrm{KOH}, 100 \mathrm{ml}$ ).

Colonial morphology. Cultures grown in glucose broth $(5 \mathrm{~g}$ each of peptone, beef extract, yeast extract, and glucose, and $1,000 \mathrm{ml}$ of distilled water; $\mathrm{pH} \mathrm{7.0)}$ were streaked on plates of tap-water agar $(15 \mathrm{~g} /$ liter $)$ The plates were incubated at $28 \mathrm{C}$ and examined under a microscope at 5,10 , and 15 days for the appearance of the colonies, the formation of substrate and aerial hyphae, and the presence of spores.

Acid production from carbohydrates. The basal inorganic nitrogen medium contained (grams per liter): $\left(\mathrm{NH}_{4}\right)_{2} \mathrm{HPO}_{4}, 1 ; \mathrm{KCl}, 0.2 ; \mathrm{MgSO}_{4} \cdot 7 \mathrm{H}_{2} 0,0.2$ agar, 15 (1). The $\mathrm{pH}$ value of this medium was adjusted to 7.0 before the addition of $15 \mathrm{ml}$ of a $0.04 \%$ solution of bromocresol purple. After this agar medium was tubed and sterilized by autoclaving, 0.5 $\mathrm{ml}$ of a $10 \%$ solution of each carbohydrate (autoclaved separately) was added aseptically to the tubes. Cultures on slants of these carbohydrate agars were observed for acid color of the indicator after 7 and 28 days of incubation at $28 \mathrm{C}$.

Decomposition of adenine, hypoxanthine, L-tyrosine, and xanthine. Adenine $(0.5 \mathrm{~g})$ was suspended in distilled water $(10 \mathrm{ml})$, autoclaved, mixed thoroughly with $100 \mathrm{ml}$ of sterile nutrient agar (peptone, $5 \mathrm{~g}$; beef extract, $3 \mathrm{~g}$; agar, $15 \mathrm{~g}$; distilled water, $1,000 \mathrm{ml}$; adjusted to $\mathrm{pH} 7.0$ ), cooled to $45 \mathrm{C}$, mixed again, and poured into sterile plates. Care was taken to obtain an even distribution of the adenine throughout the solidified agar. Each culture was streaked once across a plate, incubated at $28 \mathrm{C}$, and observed at 14 and 21 days for the disappearance of the crystals underneath and around the growth. Except in the use of $0.4 \mathrm{~g}$ of xanthine, plates of hypoxanthine, L-tyrosine, and xanthine were prepared, inoculated, and incubated in the same manner.

Decomposition of casein. A 5-g amount of skim milk powder (Difco) suspended in $50 \mathrm{ml}$ of distilled water and $1 \mathrm{~g}$ of agar in $50 \mathrm{ml}$ of distilled water were autoclaved separately and cooled to $45 \mathrm{C}$. The suspensions of milk and agar were then mixed and poured into plates. Each culture was streaked once across a plate and then incubated at $28 \mathrm{C}$. At 7 and 14 days the cultures were examined for clearing of the casein underneath and around the growth.

A heavy inoculum was used in testing for the decomposition of casein and the four amino acids (above). Some cultures grew well but did not dissolve casein or the crystals of the amino acids except around the larger clumps of inoculum.

Decomposition of urea. A $10-\mathrm{ml}$ amount of a $15 \%$ solution of urea sterilized by filtration was added to $75 \mathrm{ml}$ of sterile urease broth $\left(\mathrm{KH}_{2} \mathrm{PO}_{4}, 10 \mathrm{~g}\right.$;
$\mathrm{Na}_{2} \mathrm{HPO}_{4}, 9.5 \mathrm{~g}$; yeast extract, $1 \mathrm{~g} ; 0.04 \%$ solution of phenol red, $20 \mathrm{ml}$; distilled water, $1,000 \mathrm{ml}$; adjusted to $\mathrm{pH}$ 6.7). The mixture was pipetted aseptically in $2.5-\mathrm{ml}$ amounts into sterile plugged tubes and inoculated with actively growing cultures. An alkaline reaction after 28 days of incubation at $28 \mathrm{C}$ demonstrated the presence of urease.

Determination of diaminopimelic acid and carbohydrates. The presence and form of diaminopimelic acid (DAP) and the presence of carbohydrates in hydrolysates of whole cells were established by the chromatographic methods of Becker et al. (3) and of Lechevalier (15), respectively.

Growth at different temperatures. Slants of yeast dextrose agar (yeast extract, $10 \mathrm{~g}$; glucose, $10 \mathrm{~g}$; agar, $15 \mathrm{~g}$; tap water, $1,000 \mathrm{ml} ; \mathrm{pH} 6.8$ ) were inoculated and quickly heated or cooled to the desired temperature in a water bath. The slants were then placed in a water bath at the same temperature inside a constanttemperature incubator, with water level and temperature of bath being carefully maintained. The cultures were observed for growth after 5 days at $35 \mathrm{C}$ or above and after 3 weeks at $10 \mathrm{C}$.

Growth in Sabouraud dextrose broth. A tube of Difco Sabouraud dextrose broth (neopeptone, $10 \mathrm{~g}$; glucose, $20 \mathrm{~g}$; distilled water, $1,000 \mathrm{ml} ; \mathrm{pH} 5.7$ ) and a tube of glucose broth were inoculated from a 2- to 4-week-old culture in glucose broth in such a way that the inoculum could not be mistaken later for growth. The tubes were observed for growth after 2 and 4 weeks of incubation at $28 \mathrm{C}$.

Growth on MacConkey agar. Cultures on slants of MacConkey agar (Difco) were inoculated in the same manner and at the same time as the cultures for the determination of resistance to methyl violet and pyronin B (see below). One control culture served for the three determinations. Growth and color change of the neutral red indicator were noted after 7 and 28 days.

Hydrolysis of esculin. The cultures were inoculated into esculin broth (esculin, $1 \mathrm{~g}$; ferric citrate, $0.5 \mathrm{~g}$; peptone, $10 \mathrm{~g}$; $\mathrm{NaCl}, 5 \mathrm{~g}$; distilled water, $1,000 \mathrm{ml}$ ), incubated at $28 \mathrm{C}$, and observed for growth and blackening of the medium at 2 and 4 weeks (4). A tube of the same broth without esculin was also inoculated and used as a control.

Hydrolysis of hippurate. The hippurate broth (2) consisted of (grams per liter): tryptone, 10; beef extract, 3 ; yeast extract, 1 ; glucose, $1 ; \mathrm{Na}_{2} \mathrm{HPO}_{4}, 5$; sodium hippurate, 10. After 6 and 8 weeks of incubation, the cultures were tested for benzoic acid by mixing $1 \mathrm{ml}$ of the culture, as free of growth as possible, with $1.5 \mathrm{ml}$ of $50 \% \mathrm{H}_{2} \mathrm{SO}_{4}$. The appearance of crystals in the acid mixture after $4 \mathrm{~h}$ at room temperature indicated hydrolysis of the hippurate.

Hydrolysis of starch. Potato starch $(1.5 \mathrm{~g})$ was suspended in cold distilled water $(5$ to $10 \mathrm{ml})$ and then added to nutrient agar $(100 \mathrm{ml})$, autoclaved, cooled to $45 \mathrm{C}$, carefully mixed to suspend the starch throughout the agar, and poured into plates. Duplicate plates were streaked once across with each culture and incubated at $28 \mathrm{C}$. One plate was flooded with $95 \%$ ethanol at 5 days and the other at 10 days. After standing for 15 to $30 \mathrm{~min}$, the unchanged starch 
TABLE 1. History of strains

\begin{tabular}{|c|c|}
\hline Strain no. & Name when received, source, strain name or number \\
\hline & Nocardia autotrophica \\
\hline 1595 (ATCC 19727) & $\begin{array}{l}\text { N. autotrophica (Takamiya and Tubaki) Hirsch; H. G. Schlegel, Univ. Göttingen; } \\
\text { P. Hirsch; A. Takamiya }\end{array}$ \\
\hline 1523 & N. brasiliensis; D. Berd, Center for Disease Control, Atlanta, Ga. (147, parotid gland) \\
\hline 1357 & $\begin{array}{l}\text { N. caviae (Erikson) Gordon and Mihm; L. K. Georg, Center for Disease Control, } \\
\text { Atlanta, Ga. (B 831a, bovine mastitis) }\end{array}$ \\
\hline 3520 & N. coeliaca (Gray and Thornton) Emmart; S. A. Waksman; E. W. Emmart \\
\hline 418 & $\begin{array}{l}\text { N. coeliaca; W. C. Haynes, USDA, Peoria, Ill. (NRRL B-1365); W. T. Sokolski; E. W. } \\
\text { Emmart }\end{array}$ \\
\hline 543 & N. coeliaca; E. N. Azarowicz, Univ. of California, Los Angeles; USDA \\
\hline 703 & $\begin{array}{l}\text { N. coeliaca; C. W. Emmons, Nat. Inst. of Health, Bethesda, Md. (9964); E. W. } \\
\text { Emmart }\end{array}$ \\
\hline 704 & N. coeliaca; C. W. Emmons (9964A); E. W. Emmart \\
\hline 1337 & N. coeliaca; NCIB (8939); Boots Ltd. (116) \\
\hline 1338 & N. coeliaca; NCIB (9574); R. W. Traxler; U. A. Phillips \\
\hline 1576,1578 & N. coeliaca; L. K. Georg (W1961, W1963); L. E. Vázquez \\
\hline 1577,1579 & N. coeliaca; L. K. Georg (W1962, W1995) \\
\hline $1300,1333-1335$ & Nocardia sp.; M. P. Lechevalier, Rutgers Univ. (SS 1/1, N11, U4, 7-34; soil) \\
\hline 1309 & $\begin{array}{l}\text { Nocardia sp.; L. J. Kunz, Massachusetts General Hospital, Boston, Mass. (F 354, } \\
\text { clinical specimen) }\end{array}$ \\
\hline 1446 & Nocardia sp.; M. P. Kraus, Univ. of Delaware (RM 66A) \\
\hline 1528 & Nocardia sp.; M. P. Lechevalier (G-216, aluminum hydroxide gel) \\
\hline 1597 & $\begin{array}{l}\text { Nocardia sp.; W. A. Causey, Center for Disease Control, Atlanta, Ga. (N37, spinal } \\
\text { fluid) }\end{array}$ \\
\hline 1598 & $\begin{array}{l}\text { Nocardia sp.; L. E. Vázquez, Centro Medico de Puerto Rico, San Juan (CM 1512, } \\
\text { bronchial washing) }\end{array}$ \\
\hline 1105 & Streptomyces sp.; J. M. Mihm, Rutgers Univ. (eggplant rind) \\
\hline 1124 & Streptomyces sp.; L. K. Georg (A588) \\
\hline 1299 & Streptomyces sp.; N. F. Conant, Duke Univ. (3300, corneal ulcer) \\
\hline 1320 & $\begin{array}{l}\text { Unidentified isolation; I. Chapman, City Hospital Center, Elmhurst, N.Y. (8, spinal } \\
\text { fluid) }\end{array}$ \\
\hline \multirow[t]{2}{*}{1398} & Unidentified isolation; H. Fedukowicz, New York Univ. (TSA) \\
\hline & Nocardia asteroides \\
\hline 524,534 & N. asteroides (Eppinger) Blanchard; N. F. Conant (2221, lung; 2338, foot sinus) \\
\hline $526-528$ & $\begin{array}{l}N . \text { asteroides; N. F. Conant }(2249,2250,2251) ; \text { B. F. Fetter }(130,142,8076 ; \\
\text { abscesses) }\end{array}$ \\
\hline 530 & N. asteroides; N. F. Conant (2280); J. F. Mohn (brain abscess) \\
\hline 531 & N. asteroides; N. F. Conant (2293); W. B. VandeGrift (pus) \\
\hline 532 & N. asteroides; N. F. Conant (2298); W. E. Bray (hand lesion) \\
\hline 533 & N. asteroides; N. F. Conant (2336); S. B. Salvin (2001) \\
\hline${ }^{a}$ & N. asteroides; J. Rozanis, Western Univ. (10905) \\
\hline N630 & $\begin{array}{l}\text { N. blackwellii (Erikson) Waksman and Henrici; NCTC (630); J. McFadyean; J. T. } \\
\text { Edwards (hock joint of a foal) }\end{array}$ \\
\hline N1935 & N. cuniculi (Actinomyces sumatrae Erikson); NCTC (1935); E. P. Snijders (rabbit) \\
\hline \multirow[t]{2}{*}{1405} & $\begin{array}{l}\text { N. pasteuroides; H. A. Lechevalier; M. Goodfellow (N94); A. Gonzalez-Ochoa (35); } \\
\text { Univ. of California, Los Angeles }\end{array}$ \\
\hline & Nocardia caviae \\
\hline 402 & N. asteroides; C. W. Emmons (9975) \\
\hline 1233 & $\begin{array}{l}\text { N. asteroides; S. G. Bradley, Univ. of Minnesota (92); N. M. McClung; C. W. Emmons } \\
\text { (9903) }\end{array}$ \\
\hline 1259 & N. caviae; F. Mariat $(751)$ \\
\hline 1291 & N. caviae; R. S. Sandu, Univ. of Delhi; F. Mariat (IP 318) \\
\hline
\end{tabular}


TABLE 1.-Continued

\begin{tabular}{ll}
\hline Strain no. & Name when received, source, strain name or number \\
& \\
1315,1321 & Nocardia caviae \\
& N. caviae; L. Ajello, Center for Disease Control, Atlanta, Ga. (45-62-66, bronchial \\
washings; 45-323-66, lung of monkey) & N. caviae; L. N. Mohapatra, All India Inst. of Med. Sci., New Delhi (12, soil) \\
1316 & N. caviae; I. A. Conti Diaz, Inst. de Higiene, Montevideo (1551, soil) \\
1342 & N. caviae; L. Georg (B 812, human lung; 831 b, bovine mastitis) \\
1355,1356 & N. caviae; E. L. Biberstein, Univ. of California, Davis (359-3B, sheep lung; dog lung) \\
1365,1370 & N. caviae; A. Avram, Centrul Dermato-Venerologic, Bucharest (NCl, mycetoma) \\
1460 & N. uniformis Marton and Szabó; H. A. Lechevalier, M. Goodfellow (N3); NCIB \\
1402 & (9631) \\
& Nocardia sp.; D. B. Louria, Bellevue Hosp., New York, N. Y. \\
1203 & Nocardia sp.; C. W. Emmons (9988, mycetoma) \\
1237 & Nocardia sp.; R. S. Sandhu (SL 163); P. V. Kurup (soil) \\
1252 & Nocardia sp.; C. McDurmont, Dept. of Public Health, Montgomery, Ala. (E-51, \\
1368 & sputum) \\
& Nocardia sp.; D. Berd (78, abscess) \\
1522 & Streptomyces albus (Rossi-Doria) Waksman and Henrici; H. D. Tresner, American \\
1088 & Cyanamid Co., Pearl River, N. Y. (A0930-H-5187) \\
1073 & Streptomyces sp.; J. B. Routein, Charles Pfizer and Co., Brooklyn, N.Y. (AP 9441, \\
& 50393-036) \\
1351 & Unidentified isolation; L. D. Ashburner, Fisheries and Wildlife Dept., Alexandra, \\
& Victoria, Australia (rainbow trout)
\end{tabular}

Nocardia brasiliensis

N. brasiliensis; M. A. Gordon, Dept. of Health, Albany, N. Y. (M 4801, lesion on thigh)

N. brasiliensis; J. H. Seabury, Louisiana State Univ. (Thompson)

Nocardia sp.; M. P. Lechevalier (L 36, soil)

\section{Nocardia madurae}

N. madurae (Vincent) Blanchard; ATCC (25292A); G. Dementjeva (mycetoma pedis)

Streptomyces sp.; T. H. Stoudt, Merck and Co., Rahway, N.J. (I, "White" group)

\section{Nocardia pelletieri}

N. brasiliensis; J. H. Seabury (Walker, swelling of right mandible)

N. pelletieri (Laveran) Pinoy; M. Silva-Hutner, College of Physicians and Surgeons, New York, N. Y. (1199.38); M. A. Gordon (47293); N. F. Conant; J. B.

Fischer

Streptomyces pelletieri (Laveran) Waksman and Henrici; F. Mariat [IP 729 (red), IP 729 (white variant), IP 375-67; mycetomas]

S. pelletieri; F. Mariat (IP 372, IP 374, IP 379, IP 381, IP 726)

\section{Nocardia dassonvillei}

N. dassonvillei (Brocq-Rousseu) Liegard and Landrieu; M. P. Lechevalier (Boll 1, cotton boll)

N. dassonvillei; M. P. Lechevalier (V 116 ET); E. Tejera

$N$. dassonvillei; L. Ajello (45-286-68, cow)

Streptomyces sp.; S. A. Waksman (3564); B. S. Walker (ulcerating cancerous lesion)

Unidentified isolations; V. Rangaswamy, Government Tuberculosis Sanatorium, Madras (Madras 1, Madras 2, Madras 3A; pulmonary infections)

\footnotetext{
${ }^{a}$ Strain number not assigned.

b Nocardia otitidis-caviarum according to Lessel (Int. J. Syst. Bacteriol. 12: 191-192, 1962).
} 
became white and opaque while a clear zone underneath and around the growth measured the hydrolysis of the starch (13).

Oxidation of glucose. A modification of the Hugh and Leifson (10) test was used to determine whether the cultures utilized glucose oxidatively or fermentatively. The basal medium contained (grams per liter): peptone, $2 ; \mathrm{NaCl}, 5 ; \mathrm{K}_{2} \mathrm{HPO}_{4}, 0.3$; agar, 3. After the $\mathrm{pH}$ of the medium was adjusted to $7.1,15 \mathrm{ml}$ of a $0.04 \%$ solution of bromocresol purple was added. The semisolid agar was tubed $(7.5 \mathrm{ml}$ per $16-\mathrm{mm}$ tube), autoclaved, and quickly cooled. Before the agar solidified, $0.5 \mathrm{ml}$ of $15 \%$ aqueous solution of glucose, also sterilized by autoclaving, was added to each tube As soon as the agar solidified, duplicate tubes were inoculated by stabbing from a 2-to 4-week-old culture in glucose broth; one tube was sealed with vaspar (paraffin, 60\%; vaseline, $40 \%$ ). When the vaspar seal occasionally pulled away from the inside of the tube during the first $24 \mathrm{~h}$ of incubation at $28 \mathrm{C}$, the culture was resealed by heating the glass around the seal in a small flame. The cultures were observed at 7 and 28 days. A culture that grew and produced the acid color of the indicator in both tubes was recorded as fermenting glucose; a culture that grew in both tubes but formed the acid color only in the aerobic tube was recorded as oxidizing glucose.

Resistance to bacitracin and penicillin. A tube containing $20 \mathrm{ml}$ of yeast dextrose agar was inoculated with one or two loopfuls of a 14- to 28-day-old culture in glucose broth. The agar was carefully mixed and poured into a sterile plate. After the agar solidified, a 10-unit bacitracin sensitivity test disk (BBL) and a 10-unit penicillin sensitivity disk (Difco) were placed, by using sterile forceps, approximately 3 $\mathrm{cm}$ apart on the agar. The plates were incubated at 28 $\mathrm{C}$ and observed at 3,5, and 7 days for a zone of inhibition around the disks. If there was no growth on the plate, duplicate plates were prepared as before; disks were added to one plate, and the second plate, without disks, was incubated as a control.

Resistance to lysozyme. Glycerol broth containing $0.005 \%$ lysozyme was prepared by dissolving $0.1 \mathrm{~g}$ of lysozyme (Nutritional Biochemicals Corp., Cleveland, Ohio) in $100 \mathrm{ml}$ of distilled water in a volumetric flask and sterilizing the solution by filtration. A $5-\mathrm{ml}$ amount of the lysozyme solution was mixed with 95 $\mathrm{ml}$ of sterile glycerol broth (peptone, $5 \mathrm{~g}$; beef extract, $3 \mathrm{~g}$; glycerol, $70 \mathrm{ml}$; distilled water, $1,000 \mathrm{ml} ; \mathrm{pH} 7.0$ ) and dispensed aseptically in $2.5-\mathrm{ml}$ amounts in sterile plugged tubes. A small loopful of a 14- to 30-day-old culture in glucose or glycerol broth was inoculated into a tube of lysozyme broth and another loopful was inoculated into a tube of glycerol broth so that later the inoculum could not be mistaken for growth. After 14 and 28 days of incubation at $28 \mathrm{C}$, the cultures were observed for growth.

Resistance to methyl violet and pyronin B. Stock aqueous solutions of methyl violet and pyronin B (Matheson, Coleman, and Bell, Norwood, Ohio) were prepared by dissolving enough of the dye to result in a $1 \%$ solution of total dye content. Slants of blood agar base (Difco) containing $0.01 \%$ of the dye and $70 \mathrm{ml}$ of glycerol per liter were inoculated with a small loop ( $2.5 \mathrm{~mm}$ in outside diameter) from a 14- to 30 -day-old culture in glucose broth. Slants of the same agar without the dye were also inoculated as controls. The cultures were examined for growth after 7 and 28 days at $28 \mathrm{C}$.

Survival at $50 \mathrm{C}$. The cultures were inoculated on slants of yeast dextrose agar. The slants were heated to $50 \mathrm{C}$ in a water bath and then transferred to a water bath at the same temperature inside a constanttemperature incubator. After $8 \mathrm{~h}$ the cultures were quickly cooled, incubated at $28 \mathrm{C}$ for 3 weeks, and then examined for growth.

Utilization of benzoic, citric, and other organic acids. Modifications of Koser's (14) citrate agar were prepared by adding $2 \mathrm{~g}$ (or equivalent) of either sodium benzoate, sodium citrate, sodium lactate, calcium malate, mucic acid, sodium oxalate, or sodium succinate to: $\mathrm{NaCl}, 1 \mathrm{~g} ; \mathrm{MgSO}_{4} \cdot 7 \mathrm{H}_{2} \mathrm{O}, 0.2 \mathrm{~g}$; $\left(\mathrm{NH}_{4}\right)_{2} \mathrm{HPO}_{4}, 1.0 \mathrm{~g} ; \mathrm{KH}_{2} \mathrm{PO}_{4}, 0.5 \mathrm{~g}$; agar, $15 \mathrm{~g}$; distilled water, $1,000 \mathrm{ml} ; 0.04 \%$ solution of phenol red, $20 \mathrm{ml}$. The $\mathrm{pH}$ value of the malate agar was adjusted to 7.2 with $1 \mathrm{~N} \mathrm{NaOH}$; the $\mathrm{pH}$ value of the other agars was adjusted to 6.8 before autoclaving. Slants of the seven agars were inoculated and incubated at $28 \mathrm{C}$. Utilization of the organic acids was established by the alkaline color of the phenol red after 28 days.

\section{RESULTS}

Nocardia coeliaca. After $18 \mathrm{~h}$ of incubation at $28 \mathrm{C}$, cultures of Gray and Thornton's strain of $M$. coeliacum (ATCC 17041 and Skerman 132) grown on yeast dextrose agar were composed of gram-positive, pleomorphic rods, coccoid forms, and short filaments. At 5 days, less than $1 \%$ of the cells grown on glycerol agar were acid fast. Colonies on tap-water agar were dense and lobate, and nearly all had smooth margins. Filamentous colonies and aerial hyphae were not formed. When observed under a microscope the duplicate strains, therefore, resembled typical strains of $M$. rhodochrous (6).

Hydrolysates of whole cells of ATCC strain 17041 contained meso-DAP, arabinose, galactose, and mannose. Glucose, madurose (16), and ribose were not present. This strain conformed, therefore, to the strains of $M$. rhodochrous we have examined chromatographically. All of these (34 strains) had meso-DAP, and 15 of the 34 (the other 19 strains were not tested for carbohydrates) contained arabinose, galactose, and mannose. Madurose was not observed, and the presence of glucose and ribose was variable (Table 2 ).

Except for a weak action on tyrosine by Skerman's strain 132, physiological reactions of the duplicate strains (Table 3) were identical and in good agreement with the reactions of typical strains of $M$. rhodochrous. Positive 
TABLE 2. Carbohydrates in whole-cell hydrolysates of $M$. rhodochrous ${ }^{a}$

\begin{tabular}{l|c|c|c|c|c|c}
\hline $\begin{array}{c}\text { Strain } \\
\text { no. }\end{array}$ & $\begin{array}{c}\text { Arab- } \\
\text { inose }\end{array}$ & $\begin{array}{c}\text { Galac- } \\
\text { tose }\end{array}$ & $\begin{array}{c}\text { Glu- } \\
\text { cose }\end{array}$ & $\begin{array}{c}\text { Man- } \\
\text { nose }\end{array}$ & $\begin{array}{c}\text { Madu- } \\
\text { rose }\end{array}$ & $\begin{array}{c}\text { Ri- } \\
\text { bose }\end{array}$ \\
\hline 329 & + & + & tr & + & - & - \\
333 & + & + & tr & + & - & - \\
338 & + & + & + & + & - & tr \\
343 & + & + & - & + & - & - \\
625 & + & + & - & + & - & - \\
1339 & + & + & + & + & - & tr \\
1340 & + & + & + & + & - & - \\
3407 & + & + & - & + & - & tr \\
3408 & + & + & + & + & - & tr \\
NCTC 576 & + & + & + & + & - & $\mathrm{tr}$ \\
ATCC & + & + & - & + & - & - \\
19140 & & & & & & \\
Faur 861 & + & + & - & + & - & $\mathrm{tr}$ \\
Feeley SPU & + & + & + & + & - & $\mathrm{tr}$ \\
2301 & & & & & & \\
Little 308 & + & + & - & + & - & - \\
Seibert & + & + & + & + & - & $\mathrm{tr}$ \\
P4600 & & & & & & \\
\hline
\end{tabular}

${ }^{a}+$, Carbohydrate present; - , not present; tr, trace amount only.

characteristics ( 85 to $100 \%$ of 97 strains positive) were: hydrolysis of starch; growth at 35,28 , and $10 \mathrm{C}$; acid formation from glucose, mannitol, mannose, sorbitol, and trehalose; utilization of citrate, lactate, malate, and succinate; and oxidation of glucose. Negative properties were: decomposition of casein, hypoxanthine, and xanthine; growth at $52 \mathrm{C}$; acid formation from arabinose, dulcitol, erythritol, lactose, melibiose, $\alpha$-methyl-D-glucoside, raffinose, and rhamnose; utilization of mucate and oxalate; resistance to methyl violet, pyronin, bacitracin, and penicillin; color change of MacConkey agar; hydrolysis of hippurate; and deamination of phenylalanine. The duplicate strains formed acid from inositol and, in this respect, were like $21 \%$ of the 97 strains of $M$. rhodochrous described by Gordon (6).

Nocardia autotrophica. Although the nocardin strain and some of the other strains like it in our collection (listed under $N$. autotrophica in Table 1) had been cultivated in vitro for 25 years, the yellowish or brownish growth of the cultures on yeast dextrose agar and other media was still thickly coated with whitish aerial hyphae. Cultures on agar slants often exhibited, at the bottom of the slant, a characteristic patch of brown wrinkled growth that was more sparsely covered with aerial hyphae.

After 5 days on glycerol agar, some cultures consisted of long, branching filaments that remained intact during the preparation and staining of the smear. In other cultures, however, the branching filaments were of varying length and some had fragmented into rods and coccoid forms. Cultures of the 28 strains of $N$. autotrophica (Table 1) were not acid fast. Cultures grown on yeast dextrose agar for 2 days were gram positive. The 28 strains produced densely or loosely filamentous colonies that were soon covered with an abundance of aerial hyphae. The aerial hyphae of most strains were long, straight, and branching, whereas those of other strains were wavy or curled in loose spirals. The aerial hyphae of $37 \%$ of the cultures formed chains of cylindrical spores (conidia).

Hydrolysates of whole cells of the 28 strains contained meso-DAP, galactose and equal or greater amounts of arabinose, and mannose. Glucose was usually present; ribose was present in $50 \%$ of the cultures; and madurose was absent.

A pattern of physiological reactions for distinguishing the 28 strains of $N$. autotrophica is presented in Tables 4 and 5 . In Table 4 the physiological properties observed of four replicates of Emmart's nocardin strain (strains 418, 703,704 , and 3520) are compared with the reactions of the type strain of $N$. autotrophica (IMRU 1595, also ATCC 19727) and with those of a typical or representative strain of the 28 strains of $N$. autotrophica in our collection. The four replicates varied among themselves in four of their properties (decomposition of tyrosine, survival at $50 \mathrm{C}$ for $8 \mathrm{~h}$, reduction of nitrate to nitrite, and acid production from $\alpha$-methyl-D-glucoside), and the type strain of $N$. autotrophica differed from the replicates of the nocardin strain in three (decomposition of xanthine, acid production from inositol, and growth in Sabouraud dextrose broth). With the exception of decomposition of tyrosine, these seven reactions were variable for the 28 strains of $N$. autotrophica.

Positive physiological properties for distinguishing the 28 strains of $N$. autotrophica $(85$ to $100 \%$ of strains positive) from the six previously described (7) Nocardia species represented in our collection were: decomposition of adenine, hypoxanthine, tyrosine, and urea; utilization of citrate, lactate, malate, and succinate; hydrolysis of starch and esculin; and acid formation from adonitol, erythritol, galactose, glucose, maltose, mannitol, mannose, sorbitol, and xylose (Table 5). Negative properties ( 0 to $14 \%$ of strains positive) in this pattern of reactions were: decomposition of casein; growth at $45 \mathrm{C}$; utilization of mucate and oxalate; resistance to bacitracin, lysozyme, and penicillin; and formation of acid from dulcitol, lactose, melibiose, raffinose, and rhamnose. 
TABLE 3. Some physiological characteristics of M. rhodochrous

\begin{tabular}{|c|c|c|c|c|}
\hline \multirow[b]{2}{*}{ Property } & \multicolumn{2}{|c|}{ M. rhodochrous } & \multicolumn{2}{|c|}{$\begin{array}{c}\text { Type strain of } \\
N . \text { coeliaca }\end{array}$} \\
\hline & $\begin{array}{l}97 \text { strains } \\
\text { (\% positive) }\end{array}$ & $\begin{array}{l}\text { Typical } \\
\text { strain }\end{array}$ & $\begin{array}{l}\text { ATCC } \\
17041\end{array}$ & $\begin{array}{c}\text { Skerman } \\
132\end{array}$ \\
\hline \multicolumn{5}{|l|}{ Decomposition of } \\
\hline Casein & 0 & - & - & - \\
\hline Hypoxanthine & 2 & - & - & - \\
\hline Tyrosine & 74 & + or - & - & \pm \\
\hline Xanthine & 0 & - & - & - \\
\hline Hydrolysis of starch & 97 & + & + & + \\
\hline \multicolumn{5}{|l|}{ Growth at } \\
\hline $52 \mathrm{C}$ & 3 & - & - & - \\
\hline $45 \mathrm{C}$ & 46 & + or - & - & - \\
\hline $40 \mathrm{C}$ & 70 & + or - & - & - \\
\hline $35 \mathrm{C}$ & 91 & + & + & + \\
\hline $28 \mathrm{C}$ & 100 & + & + & + \\
\hline $10 \mathrm{C}$ & 100 & + & + & + \\
\hline \multicolumn{5}{|l|}{ Acid from } \\
\hline $1(+)$ Arabinose & 8 & - & - & - \\
\hline Dulcitol & 0 & - & - & - \\
\hline i-Ery thritol & 7 & - & - & - \\
\hline Glucose & 99 & + & + & + \\
\hline i-Inositol & 21 & + or - & + & + \\
\hline$d(+)$ Lactose & 0 & - & - & - \\
\hline d (-) Mannitol & 99 & + & + & + \\
\hline d (+) Mannose & 99 & + & + & + \\
\hline d (+) Melibiose & 0 & - & - & - \\
\hline$\alpha$-Methyl-D-glucoside & 0 & - & - & - \\
\hline d (+) Raffinose & 0 & - & - & - \\
\hline 1 (+) Rhamnose & 9 & - & - & - \\
\hline d-Sorbitol & 100 & + & + & + \\
\hline d (+) Trehalose & 97 & + & + & + \\
\hline \multicolumn{5}{|l|}{ Utilization of } \\
\hline Benzoate & 70 & + or - & - & - \\
\hline Citrate & 90 & + & + & + \\
\hline Lactate & 100 & + & + & + \\
\hline Malate & 99 & + & + & + \\
\hline Mucate & 0 & - & - & - \\
\hline Oxalate & 0 & - & - & - \\
\hline Succinate & 100 & + & + & + \\
\hline \multicolumn{5}{|l|}{ Resistance to } \\
\hline Methyl violet & 0 & - & - & - \\
\hline Pyronin & 0 & - & - & - \\
\hline Bacitracin & $0^{a}$ & - & - & - \\
\hline Penicillin & 6 & - & - & - \\
\hline Color change of MacConkey agar & 0 & - & - & - \\
\hline Hydrolysis of hippurate & 9 & - & - & - \\
\hline Deamination of phenylalanine & 12 & - & - & - \\
\hline Oxidation of glucose & 99 & + & + & + \\
\hline
\end{tabular}

${ }^{a}$ Fifty-two strains examined.

Although not all the physiological tests were applied to our strains of $M$. rhodochrous (Table 3 ), decomposition of hypoxanthine ( $92 \%$ of the strains of $N$. autotrophica positive) and production of acid from erythritol ( $100 \%$ positive), in addition to the morphological features, separ- ated the strains of $N$. autotrophica from strains of the rhodochrous complex. To a lesser extent, decomposition of xanthine $(79 \%$ of the strains positive) and acid formation from arabinose ( $82 \%$ positive) were helpful in dividing the two taxa. 


\section{DISCUSSION}

ATCC 17041, one of Gray and Thornton's (8) original isolates of $M$. coeliacum, now known as Nocardia coeliaca, has been designated herein as the type strain of $N$. coeliaca.
Because the nocardin-producing strain of Emmart (5) and others like it form filamentous colonies and an abundance of aerial hyphae, Gray and Thornton, and Jensen $(11,12)$ would not have assigned them to the genus Mycobacterium. The morphological separation of the

TABLE 4. Some properties of the nocardin-producing strain and of strains of $N$. autotrophica

\begin{tabular}{|c|c|c|c|c|c|c|}
\hline \multirow{2}{*}{ Property } & \multicolumn{4}{|c|}{ Nocardin strain } & \multicolumn{2}{|c|}{ N. autotrophica } \\
\hline & 418 & 703 & 704 & 3520 & Type strain & Typical strain \\
\hline Acid fastness & - & - & - & - & - & - \\
\hline Decomposition of & & & & & & \\
\hline Adenine & + & + & + & + & + & + \\
\hline Casein & - & - & - & - & - & - \\
\hline Hypoxanthine & + & + & + & + & + & + \\
\hline Tyrosine & + & - & + & + & + & + \\
\hline Urea & + & + & + & + & + & + \\
\hline Xanthine & + & + & + & + & - & + or - \\
\hline \multicolumn{7}{|l|}{ Growth at } \\
\hline $45 \mathrm{C}$ & - & - & - & - & - & - \\
\hline $10 \mathrm{C}$ & + & + & + & + & + & + or - \\
\hline Survival at $50 \mathrm{C}$ for $8 \mathrm{~h}$ & - & - & - & + & - & + or - \\
\hline Nitrate from nitrite & + & + & - & + & + & + or - \\
\hline \multicolumn{7}{|l|}{ Acid from } \\
\hline Adonitol & + & + & + & + & + & + \\
\hline $1(+)$ Arabinose & + & + & + & + & + & + or - \\
\hline Dulcitol & - & - & - & - & $=$ & - \\
\hline i-Ery thritol & + & + & + & + & + & + \\
\hline$d(+)$ Galactose & + & + & + & + & + & + \\
\hline Glucose & + & + & + & + & + & + \\
\hline i-Inositol & - & - & - & - & + & + or - \\
\hline d (+) Lactose & - & - & - & - & - & - \\
\hline d (+) Maltose & + & + & + & + & + & + \\
\hline d (-) Mannitol & + & + & + & + & + & + \\
\hline$d(+)$ Mannose & + & + & + & + & + & + \\
\hline d (+) Melibiose & - & - & - & - & - & - \\
\hline$\alpha$-Methyl-D-glucoside & + & - & + & + & - & + or - \\
\hline d (+) Raffinose & - & - & - & - & - & - \\
\hline $1(+)$ Rhamnose & - & - & - & - & - & - \\
\hline d-Sorbitol & + & + & + & + & + & + \\
\hline d (+) Xylose & + & + & + & + & + & + \\
\hline \multicolumn{7}{|l|}{ Utilization of } \\
\hline Benzoate & - & - & - & - & - & - \\
\hline Citrate & + & + & + & + & + & + \\
\hline Lactate & + & + & + & + & + & + \\
\hline Malate & + & + & + & + & + & + \\
\hline Mucate & - & - & - & - & - & - \\
\hline Oxalate & - & - & - & - & - & - \\
\hline Succinate & + & + & + & + & + & + \\
\hline \multicolumn{7}{|l|}{ Resistance to } \\
\hline Bacitracin & - & - & - & - & - & - \\
\hline Lysozyme & _- & - & - & - & - & - \\
\hline Penicillin & - & - & - & - & - & - \\
\hline \multicolumn{7}{|l|}{ Hydrolysis of } \\
\hline Esculin & + & + & + & + & + & + \\
\hline Hippurate & - & - & - & - & - & + or - \\
\hline Starch & + & + & + & + & + & + \\
\hline $\begin{array}{l}\text { Growth in Sabouraud } \\
\text { dextrose broth }\end{array}$ & + & + & + & + & - & + or - \\
\hline
\end{tabular}


TABLE 5. Some properties of seven species of Nocardia

\begin{tabular}{|c|c|c|c|c|c|c|c|}
\hline \multirow[b]{2}{*}{ Property } & \multicolumn{7}{|c|}{ Positive strains (\%) } \\
\hline & $\begin{array}{c}N . \\
\text { aster- } \\
\text { oides } \\
(137)^{a}\end{array}$ & $\begin{array}{c}N . \\
\text { caviae } \\
\text { (37) }\end{array}$ & $\begin{array}{c}N . \\
\text { brasil- } \\
\text { iensis } \\
(65)\end{array}$ & $\begin{array}{c}N . \\
\text { auto- } \\
\text { trophica } \\
(28)\end{array}$ & $\begin{array}{c}N . \\
\text { madurae } \\
(46)\end{array}$ & $\begin{array}{l}N . \\
\text { pelle- } \\
\text { tieri } \\
(25)\end{array}$ & $\begin{array}{c}N . \\
\text { dasson- } \\
\text { villei } \\
(33)\end{array}$ \\
\hline Acid fastness & 60 & 62 & 82 & 0 & 0 & 0 & 0 \\
\hline \multicolumn{8}{|l|}{ Decomposition of } \\
\hline Adenine & 0 & 3 & 3 & 92 & 0 & 0 & 100 \\
\hline Casein & 0 & 0 & 98 & 0 & 98 & 100 & 97 \\
\hline Hypoxanthine & 4 & 100 & 95 & 92 & 98 & 76 & 100 \\
\hline Tyrosine & 1 & 5 & 100 & 89 & 93 & 100 & 100 \\
\hline Urea & 96 & 100 & 100 & 86 & 0 & 0 & 36 \\
\hline Xanthine & 0 & 100 & 0 & 79 & 0 & 0 & 100 \\
\hline \multicolumn{8}{|l|}{ Growth at } \\
\hline $45 \mathrm{C}$ & 41 & 38 & 2 & 0 & 35 & 68 & 0 \\
\hline $10 \mathrm{C}$ & 16 & 24 & 38 & 82 & 0 & 0 & 0 \\
\hline Survival at $50 \mathrm{C}$ for $8 \mathrm{~h}$ & 96 & 97 & 2 & 64 & 100 & 100 & 97 \\
\hline Nitrite from nitrate & 91 & 97 & 91 & 54 & 98 & 100 & 91 \\
\hline \multicolumn{8}{|l|}{ Utilization of } \\
\hline Benzoate & 0 & 0 & 0 & 36 & 7 & 0 & 0 \\
\hline Citrate & 34 & 38 & 100 & 96 & 83 & 0 & 97 \\
\hline Lactate & $46^{b}$ & 62 & 100 & 100 & 98 & 24 & 100 \\
\hline Malate & 96 & 100 & 100 & 100 & 7 & 52 & 100 \\
\hline Mucate & & 5 & & 0 & & 0 & 0 \\
\hline Oxalate & & 0 & $0^{c}$ & 4 & 0 & 0 & 0 \\
\hline Succinate & 95 & 100 & 100 & 100 & 83 & 0 & 100 \\
\hline \multicolumn{8}{|l|}{ Resistance to } \\
\hline Bacitracin & & & & 0 & & & \\
\hline Lysozyme & 100 & 100 & 100 & 0 & 9 & 0 & 0 \\
\hline \multirow{2}{*}{\multicolumn{8}{|c|}{ Hydrolysis of }} \\
\hline & & & & & & & \\
\hline Esculin & $100^{c}$ & 100 & $100^{c}$ & 89 & 98 & 0 & 9 \\
\hline Hippurate & & & & 18 & 4 & 0 & 100 \\
\hline Starch & 69 & 51 & 60 & 100 & 100 & 0 & 100 \\
\hline \multicolumn{8}{|l|}{ Acid from } \\
\hline Adonitol & 1 & 3 & 0 & 92 & 91 & 0 & 0 \\
\hline $1(+)$ Arabinose & 0 & 14 & 0 & 82 & 100 & 0 & 58 \\
\hline Dulcitol & $0^{b}$ & 0 & $0^{c}$ & 0 & 0 & 0 & 0 \\
\hline i-Erythritol & 5 & 0 & 0 & 100 & 0 & 0 & 0 \\
\hline d (+) Galactose & 18 & 8 & 95 & 96 & 87 & 0 & 58 \\
\hline Glucose & 99 & 100 & 98 & 100 & 100 & 100 & 100 \\
\hline i-Inositol & 3 & 100 & 100 & 32 & 61 & 0 & 0 \\
\hline d (+) Lactose & 0 & 0 & 0 & 0 & 55 & 0 & 0 \\
\hline d (+) Maltose & 0 & 8 & 3 & 85 & 55 & 0 & 100 \\
\hline $\mathrm{d}(-)$ Mannitol & 1 & 86 & 95 & 100 & 100 & 0 & 100 \\
\hline$d(+)$ Mannose & 16 & 35 & 69 & 100 & 93 & 0 & 94 \\
\hline d (+) Melibiose & $0^{b}$ & 0 & $0^{c}$ & 0 & 0 & 0 & 9 \\
\hline$\alpha$-Methyl-D-glucoside & 0 & 0 & 0 & 43 & 0 & 0 & 24 \\
\hline d (+) Raffinose & 0 & 0 & 0 & 0 & 0 & 0 & 0 \\
\hline 1 (+) Rhamnose & 32 & 3 & 3 & 14 & 100 & 0 & 55 \\
\hline d-Sorbitol & 0 & 3 & 0 & 96 & 0 & 0 & 0 \\
\hline d (+) Xylose & 0 & 5 & 2 & 100 & 100 & 0 & 70 \\
\hline $\begin{array}{l}\text { Growth in Sabouraud } \\
\text { dextrose broth }\end{array}$ & $94^{b}$ & 97 & $96^{c}$ & 75 & 15 & 0 & 3 \\
\hline
\end{tabular}

${ }^{a}$ Numbers in parentheses indicate the number of strains examined.

$b$ Ninety strains examined.

${ }^{c}$ Fifty strains examined. 
nocardin strains from the type strain of $N$. coeliaca is supported by physiological criteria and, according to the examination of a limited number of strains, by their lipids. Lechevalier, Horan, and Lechevalier (17) reported that eight strains of the rhodochrous complex, to which the type strain of $N$. coeliaca belongs, contained nocardomycolic acids, whereas four nocardin strains $(1105,1124,1320,1337)$ had no nocardomycolic or mycolic acids. We are convinced, therefore, that the nocardin strains are mistakenly labeled $N$. coeliaca.

Among the strains in our collection like Emmart's nocardin-producing strain, the type strain of $N$. autotrophica is the only one providing a name for the species we believe to be distinct. The widespread distribution of the nocardin strains under the name $N$. coeliaca is unfortunate, but a complete elimination of the mislabeling should be pursued no matter how discouraging.

\section{ACKNOWLEDGMENTS}

This work was supported in part by Public Health Service grant AI-06276 from the National Institute of Allergy and Infectious Diseases. We are grateful for this support and for the assistance of the investigators who sent us their strains.

\section{REPRINT REQUESTS}

Address reprint requests to: Dr. Ruth E. Gordon, Institute of Microbiology, Rutgers University, the State University of New Jersey, New Brunswick, N. J. 08903.

\section{LITERATURE CITED}

1. Ayers, S. H., P. Rupp, and W. T. Johnson, Jr. 1919. A study of the alkali-forming bacteria found in milk. Bull. no. 782, U. S. Department of Agriculture.

2. Baird-Parker, A. C. 1963. A classification of micrococci and staphylococci based on physiological and biochemical tests. J. Gen. Microbiol. 30:409-427.

3. Becker, B., M. P. Lechevalier, R. E. Gordon, and H. A. Lechevalier. 1964. Rapid differentiation between Nocardia and Streptomyces by paper chromatography of whole-cell hydrolysates. Appl. Microbiol. 12:421-423.
4. Cowan, S. T., and K. J. Steel. 1965. Manual for the identification of medical bacteria. University Press, Cambridge.

5. Emmart, E. W. 1947. A new tuberculostatic antibiotic from a species of Nocardia. Amer. Rev. Tuberc. Pulm. Dis. 56:316-333.

6. Gordon, R. E. 1966. Some strains in search of a genus-Corynebacterium, Mycobacterium, Nocardia or what? J. Gen. Microbiol. 43:329-343.

7. Gordon, R. E., and A. C. Horan. 1968. Nocardia dassonvillei, a macroscopic replica of Streptomyces griseus. J. Gen. Microbiol. 50:235-240.

8. Gray, P. H. H., and H. G. Thornton. 1928. Soil bacteria that decompose certain aromatic compounds. Zentrabl. Bakteriol. Parasitenk. Infektionskr. Hyg. Abt. II, 73:74-96.

9. Hirsch, P. 1961. Wasserstoffaktivierung und Chemoautotrophie bei Actinomyceten. Arch. Mikrobiol. 39:360-373.

10. Hugh, R., and E. Leifson. 1953. The taxonomic significance of fermentative versus oxidative metabolism of carbohydrates by various gram-negative bacteria. J. Bacteriol. 66:24-26.

11. Jensen, H. L. 1931. A note on the systematic position of Mycobacterium coeliacum. Proc. Linnean Soc. New South Wales 56:201-203.

12. Jensen, H. L. 1934. Studies on saprophytic mycobacteria and corynebacteria. Proc. Linnean Soc. New South Wales 59:19-61.

13. Kellerman, K. F., and I. G. McBeth. 1912. The fermentation of cellulose. Zentrabl. Bakteriol. Parasitenk. Infektionskr. Hyg. Abt. II 34: 485494.

14. Koser, S. A. 1924. Correlation of citrate utilization by members of the colon-aerogenes groups with other differential characteristics and with habitat. J. Bacteriol. 9:59-77.

15. Lechevalier, M. P. 1968. Identification of aerobic actinomy cetes of clinical importance. J. Lab. Clin. Med. 71:934-944.

16. Lechevalier, M. P., and N. N. Gerber. 1970. The identity of madurose with 3-0-methyl-D-galactose. Carbohyd. Res. 13:451-454.

17. Lechevalier, M. P., A. C. Horan, and H. A. Lechevalier. 1971. Lipid composition in the classification of nocardiae and mycobacteria. $\mathbf{J}$. Bacteriol. 105:313-318.

18. Takamiya, A., and K. Tubaki. 1956. A new form of streptomyces capable of growing autotrophically. Arch. Mikrobiol. 25:58-64.

19. Waksman, S. A., and A. T. Henrici. 1948. Family II. Actinomycetaceae Buchanan, p. 892-928. In R. S. Breed, E. G. D. Murray, and A. P. Hitchens (ed.), Bergey's manual of determinative bacteriology, 6th ed. The Williams \& Wilkins Co, Baltimore. 